\title{
TENEMENT HOUSE "UNDER THE GOLDEN CROWN" IN WROCŁAW - RENOVATION OF THE PECULIAR MONUMENT
}

\author{
Krystyna KIRSCHKE ${ }^{1}$ \\ Wroclaw University of Technology, \\ Faculty of Architecture, Wroclaw, Poland
}

\begin{abstract}
Among the many historic buildings in Wroclaw, there is a property address Rynek 29 Oławska 2, that in 1970 entered in the register of monuments as "a department store, earlier tenement house called " Under the Golden Crown". In the fact it was built in 1961 and it is neither a historical building nor department store. It is, spectacular example of creative retrospective, in the post-war reconstruction of Wroclaw. It has relict of medieval and Renaissance architecture, but the aboveground parts have a skeleton structure of commercial buildings from the early 20th century. In recent years, there is a problem with renovating such buildings. Recognition of these monuments has become a requirement now. Because only in this way in the future, in the course of modernization works, you will be able to avoid bad decisions and unforeseen situations.
\end{abstract}

Keywords: Wroclaw, post-war reconstruction, the historic tenement house

\section{INTRODUCTION}

Among the many historic buildings of Wroclaw, there is the object of the address of Rynek 29 - Oławska 2 street, listed as a monument in 1970. As the "Department store, former tenement "Under the Golden Crown ". Its peculiarity lies in the fact that it was built in 1958-1961 on the basis of the steel skeleton of the department store "Zur Goldenen Krone "(built in 1904 and burned in 1945),

\footnotetext{
${ }^{1}$ Corresponding author: Wroclaw University of Technology, Faculty of Architecture, Bolesława Prusa st 53/53, 50-377 Wrocław, Poland, e-mail: krystyna.kirschke@ pwr.wrocedu.pl, tel. +48713206564
} 
and it is neither a historical tenement nor a department store. This object, in the post-war, is a particular example of a retrospective creation involving the erection of important construction of the Old Town, not necessarily faithfully reproduced and not necessarily located in its original location. Since they were created on the clearcuttings of historic buildings, in their structure we can find fragments of an earlier era houses, including buildings from the early twentieth century. Erected on the basis of these elements, service and residential homes, thanks to styling of facades, they quickly blended in with the landscape of the Market and after a few years gained the rank of registered monuments. In recent years, there was a problem with modernization of such buildings, resulting from pressure on the owners to invest in them profitable commercial functions, such as banks, shops, offices or hotels. Recognition of these monuments is a requirement of the moment, otherwise, at the time of conversion, there may occur unforeseen situations and bad decisions making. A spectacular example of this type of situation is the restoration of today's "Golden Crown".

\section{TRANSFORMATION OF BUILDINGS ON THE PARCEL RYNEK 29}

\subsection{Tenement house „Zur Goldenen Krone”}

Brick building on the southeast corner of the Market appeared at the beginning of the thirteenth century. In the years 1521-1528 on clearcuts of Gothic building one erected first of Wroclaw, Renaissance patrician home, which attic, resembling a crown, became a model for many Silesian structures [3, 8]. This building, presumably by Vincentius de Parmetana, was cellared,4-storey and two-sectioned. By market facade was 6-axial and 3-axial from the Oławska street. One placed stone portal in the center of the ground floor (Fig. 1b), leading to the crossing hall, flanked by small windows. The openings on the upper floors were grouped by embrasing of profiled ledges, under and onwindowed and decorated with stone frames with fascia. Originally the house was covered with a flat or recessed roof, later one made high mansard roof on a part from the Market [7]. In the third decade of the sixteenth century corner building was combined with the two houses adjoining to the east along the Oławska street (Fig. 1a). Their fusion was achieved by establishing a common courtyard, equipped on three floors with the outer galleries based on stone brackets. Thanks to this idea, deep one-tracked rooms were available without having to create the enfilade system. In the nineteenth century excellent location of the building made it perfect for locating of shops and banks. Object was first modernized by remodeling the ground floor, where one made showcases and 
stand-alone entrance to the service, and then also the higher floors. At the end of the century, due to the huge demand for commercial space in the area of Market, this type of activity, became far inadequate, though.
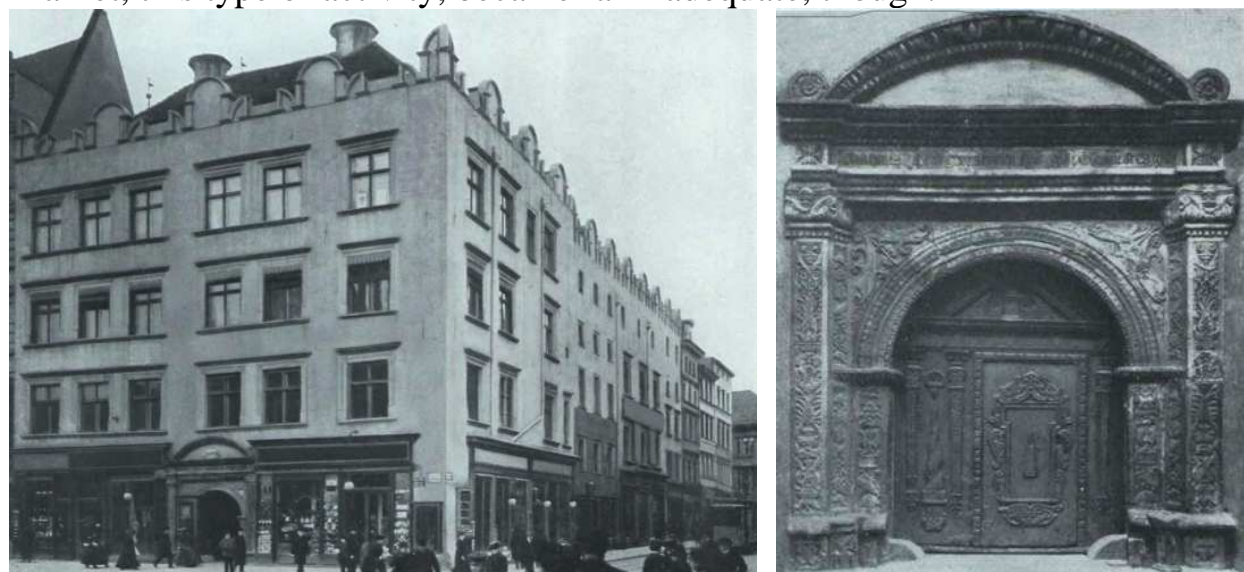

Fig. 1a, 1b. Building "Zur goldenen Krone" and its portal by the end of XIX c

\section{2. "Geschäftshaus Goldenen Krone", 1904-1945}

In 1902, despite protests from conservationists, the company "Goldene Krone" decided to demolish the renaissance building and replace it with modern department store. The project was commissioned to architects of Kayser \& Groszheim Company from Berlin, who decided to give the object a monumental, Art Nouveau-Renaissance form [4, 5]. They suggested fashionable, at that time in the big cities of Europe, multifunctional structure: eight shops on the ground floor, a huge cafeteria above, followed floors of offices for renting (Fig. 2).

Building was erected on the changed building lines, because of which from the Market one managed to expand the inlet of Świdnicka street. On the ground floor, where dominated large windows, one placed neo-Renaissance stone portal. The next two floors were equipped with similar showcases. Above the rhythm of windows was concentrated. Design was complemented with windows bays with rich ornamentation and massive roofs with gables and lucarnes. Corner was accentuated with a tower, which was completed with a gilded crown. Introduced technology and material solutions, met modern requirements and building codes. One used steel frame construction, which included facade pillars made of bolted steel beams, internal circular columns and stored in the basement, ground floor and first floor, medieval masonry gable walls. On them, one based steel bolts and ceilings made of hollow ceramic Klein type. Twostorey roofs also had a steel structure [1]. Designed object, despite these 
protests of defenders of Renaissance building, were erected quickly. As it was assumed, it perfectly met the expectations of investors: allowing the smooth functioning of the shopping and offices in it. Placed on the floor "Café zur Goldenen Krone" continued the traditions of the restoration of this place. There also took place art concerts every day. On the second floor, was opened a large billiard room with twelve tables (Fig. 3).

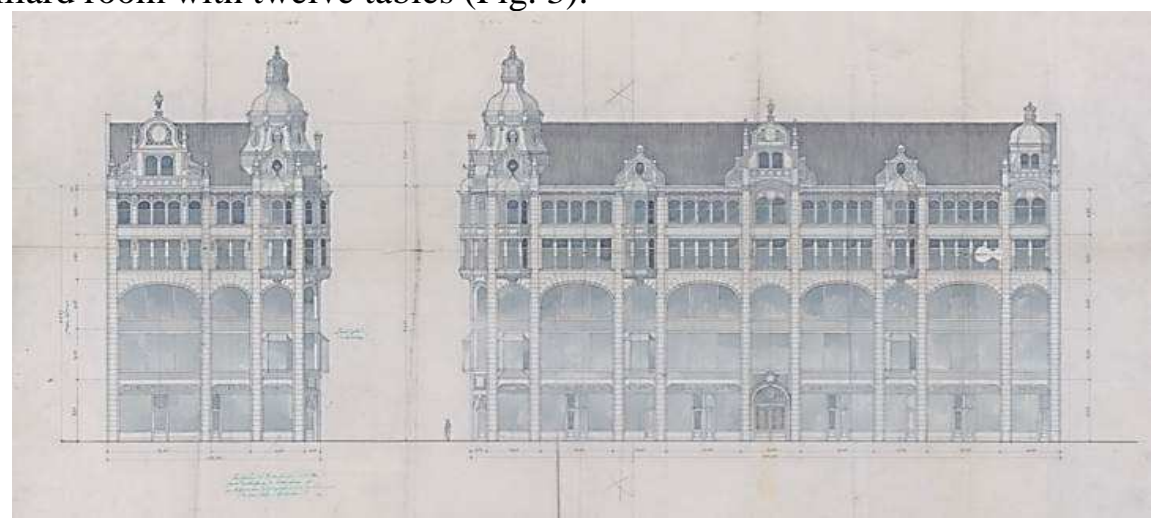

Fig. 2. Project of facades "Geschäftshaus Zur goldenen Krone", architects Kayser \& Groszheim, 1903

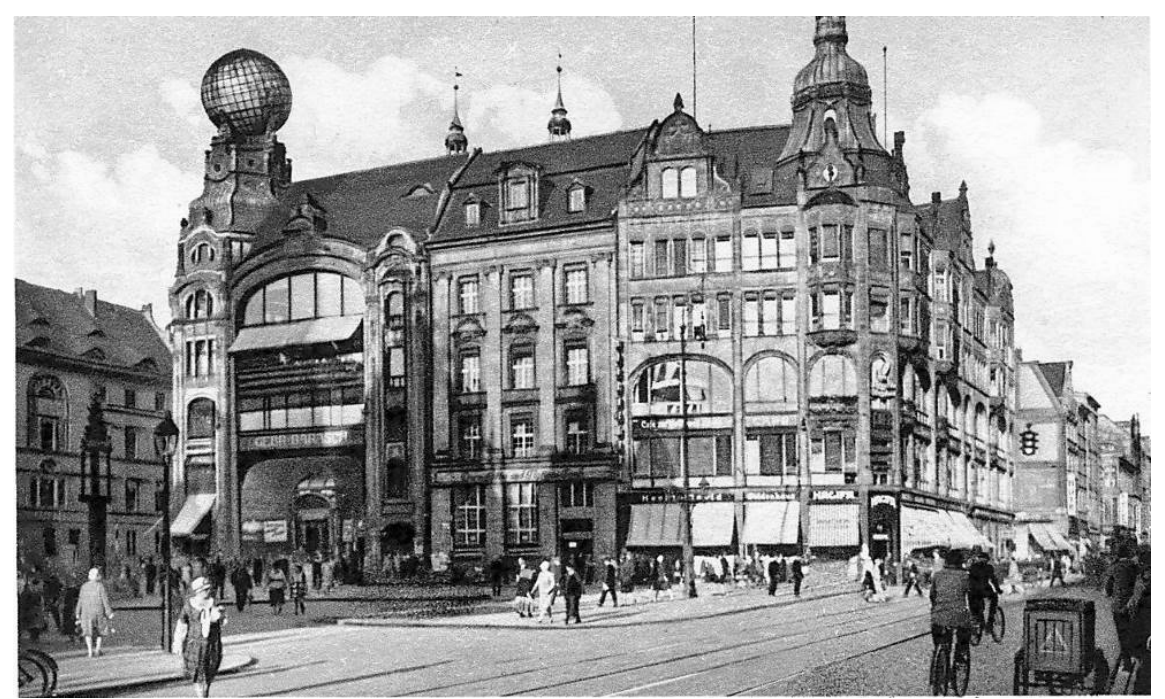

Fig. 3. Commercial property of eastern frontage of the Market, from the left: "Werenhaus Barasch", "Breslauer Disconto-Bank",

"Geschäftshaus zur goldenen Krone", 1905 


\subsection{Office building "Under the Crown"}

During the siege of Wroclaw in 1945, destruction of roofs and interior of the building were done. However, the steel structure and massive ceilings survived, thanks to which, immediately after the war, building avoided demolition. For several years, there had been held, in Wroclaw, city cleaning process of rubble, ruins, and the reconstruction of the most important monuments. Then, according to the so-called Zachwatowicz Plan, one decided that in the Market and the Solny Square residential buildings will be restored with the trade on the ground floor. Their facades were formally refered to the historic homes from about 1800 [10]. As a result of this action, many modern commercial buildings disappeared from the landscape of Wroclaw. Ruin of "Goldene Krone" was still standing, and trade functioned on the ground floor. It was only the changes after the 1956, when the pressure on the construction of residential buildings lessened, it was decided to give the Project Office building of the city of Wroclaw (BPmW), which was to be headquartered from here [2]. The main designer was the architect Zbigniew Politowski [9]. Implementation started in 1958. (Fig. 4a).
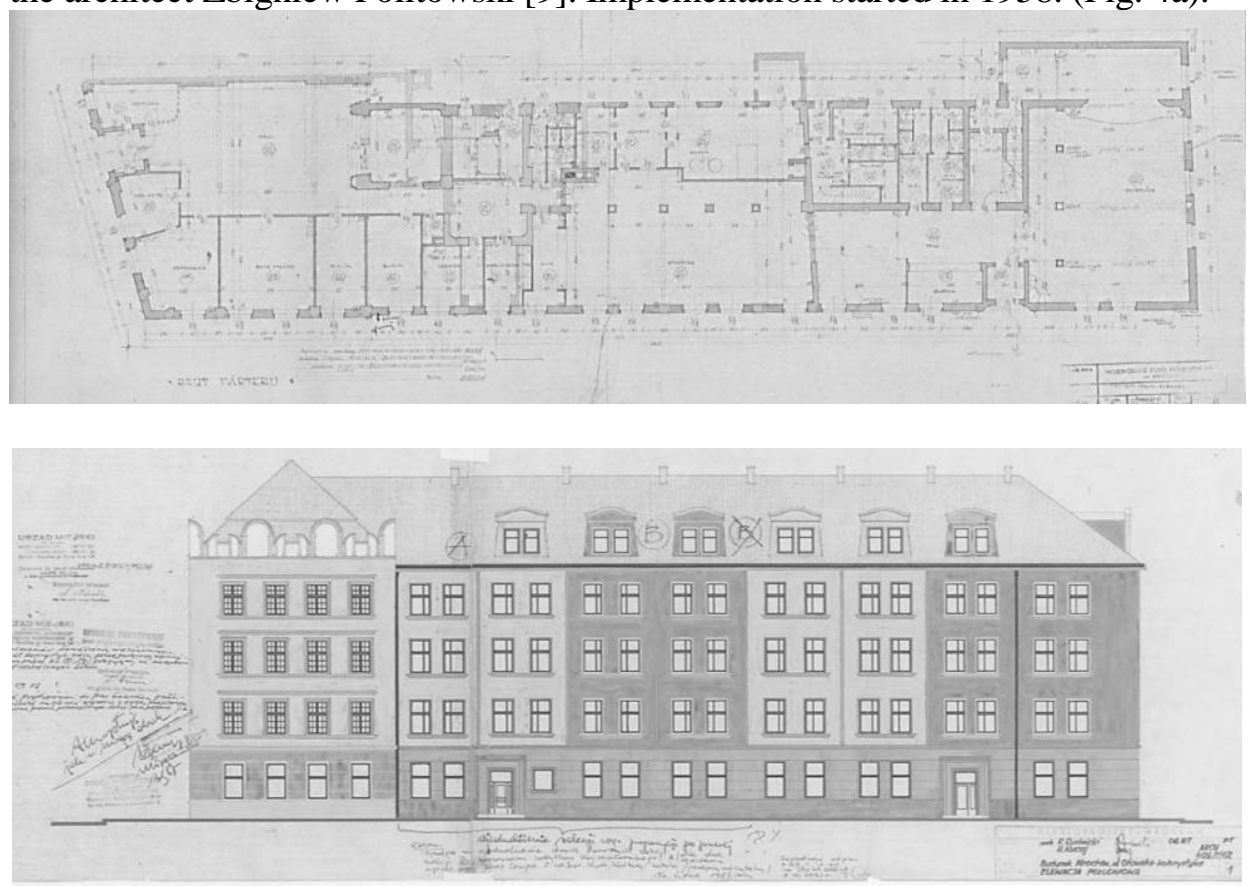

Fig. 4a i 4b. Building remodeling project Market 29 Oławska 2 street, from 1956 and executed in 1987 the design of colour changes of southern elevation 

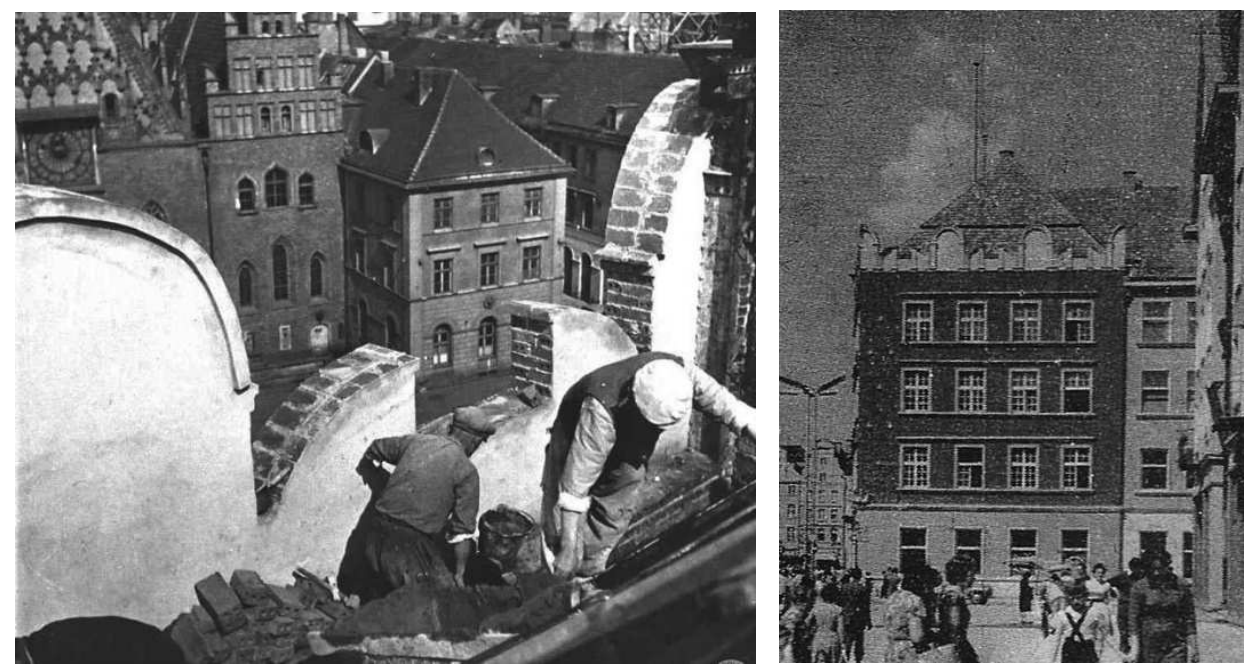

Fig. 5a i 5b. Roofing in 1960 and southern elevation in 1961

On the reconstruction one decided to use reduced to four-storey steel frame of the former department store (within the roof one preserved part of the fifth floor). Corner fragment was given a form inspired by the architecture previously described Renaissance building. Facade wall was added in front of the structural columns (four from the Market and six from the Oławska street). From the Market, in a 3-storey, 5-axial facade windows on the upper floors were grouped of two and three, stringing with cornices on the lines of windowsills and above the lintels. From the Oławska street, four axes of equally spaced windows were combined in a similar manner (Fig. 4b). In the rusticated ground floor from the Market, one built in moved from another house renaissance portal, and in axes of epper floors, one placed showcased windows. At the corner above the plinth ledge, one built in, referring to the name a ceramic crown. Both facades were crowned with continuous parapet modeled on historical one(Fig. 5a). Another part of the building along the Oławska street was slightly withdrawn and treated as a separate object. The facade was symmetrical, 16-axial (nine of which were within the preserved skeleton) looked contemporary, but had the same number of floors, aligned levels, identical windows and dipped roof. Commissioned in 1961 to use building at that time was quite a luxury; it had central heating and a lift, one even planned an underground garage (Fig. 5b).

Over the next 50 years, when the bank and a travel agency Orbis operated next to the projects office, the building had undergone only minor upgrades and current repairs. In 2011 it was put on sale for the purpose of the" centre-art service ". It was purchased by the ZPO "Otis" company. The main problem was 
outdated use structure and archaic technical solutions. Immediately one began to wonder of a new way of operation of the facility and one instructed engineering construction expertise and conservation research. As a result, the structure of the monument was recognized and defined the value of authentic matter, irregardless from what period it came from. In a historic building of this type, in which there was a multiple historical and stylish layers, and scheduled and technological, very important was to link these facts and valuation of decisions. The priority was to preserve the medieval and Renaissance brick gables, but it was equally important to respect the unique design from 1904, and the key elements of the composition of the facade made in the 1960, in the part Renaissance styled. This made it possible to take appropriate conservation decisions. Crucial was to find a suitable program that would correspond to the structure of the building and was commercially attractive. Held responsible were centre-art services on the ground floor (two banks and shops), a large restaurant in the basement and a hotel on the upper floors. Some of these tasks were implemented in 2013 according to the construction project (Fig. 6a) developed by Krystyna and Paweł Kirschke [6]. Work started for the renovation of the facades. Repairs of the structures were made within the ground floor the maintenance of stone and plasterwork was carried out. Additional entrances were also made to all the services and information and advertising elements (Fig. 6b).
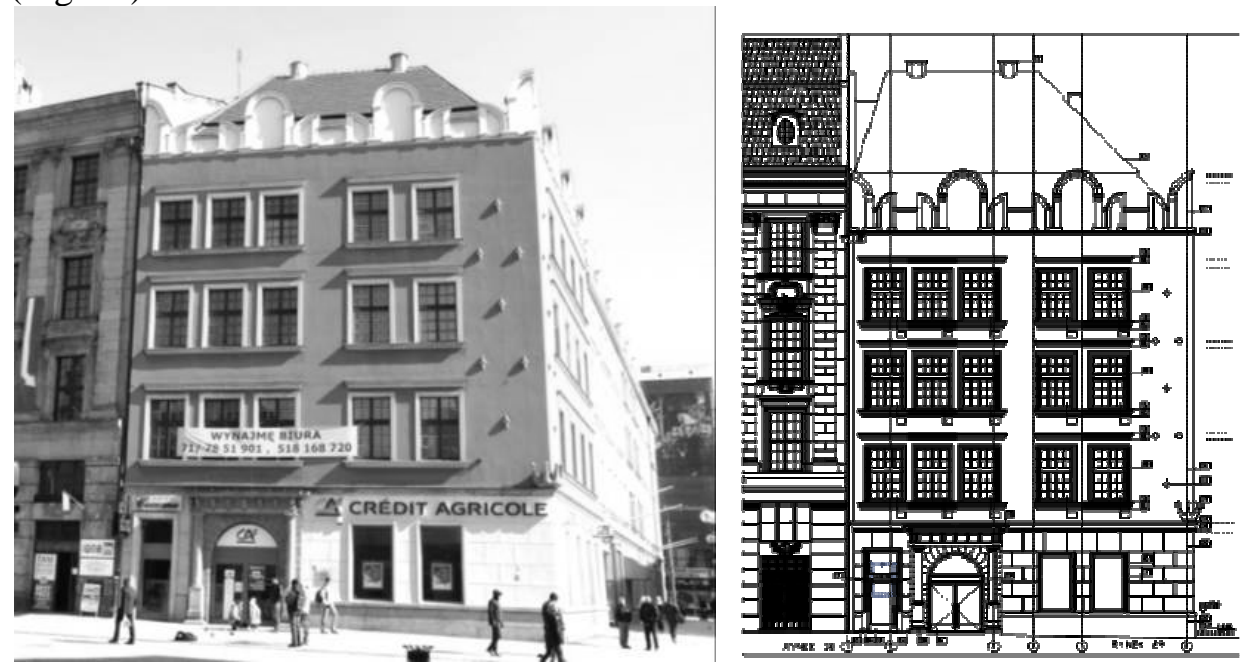

Fig. 6a, 6b. Market 29 building remodeling project - Oławska 2. Facade of Market ,Kirschke Design Studio, 2013 Building "Under the Crown", the state of 2014 


\section{CONCLUSIONS}

Today, the most desirable in the historical center of Wroclaw functions are dining, shopping and banks. They perfectly attract functioning of Wrocław's Old Town, maintaining its urban character. Therefore, in the created after World War II "pre-industrial monuments" such as house, "Under the Crown", one repeates sequence of events that already taken place in the late nineteenth century. In many places continue reconstruction allowing them to efficiently operate in the demanding market of services - are adapted to modern technical and functional requirements. Inherited from the department stores, spatial layouts and structures are susceptible to this type of modernization, but the greed of investors and the scale of reconstructions are a great threat to them even though they are protected as registered monuments. Currently in the public consciousness corner part of the building operates as an authentic Renaissance building, which was reconstructed after World War II. Given the uniqueness of this architecture and compositional qualities of facades, as well as the detail and quality of craft work, insights into the details of the ennoblement of the pseudostyle architecture seems to be irrelevant. Instead, one must promote knowledge of this type of architecture and its uniqueness.

\section{REFERENCES}

1. Archiwum Budowlane miasta Wrocławia, T. 2600, 3724, 5070-5072.

2. Archiwum Państwowe we Wrocławiu, sygn. 205, 288, 289, 290, 315.

3. Burgermeister L.: Das Haus zur goldenen Krone, Schlesiens Vorzeit in Bild und Schrift. Zeitschrift des Vereines für das Museum Schlesischer Altertümer, 3 (1904) 93-99.

4. Die Goldene Krone in Breslau, Ostdeutsche Bau-Zeitung, 8(1905), 576.

5. Geschäftshaus zur Goldenen Krone in Breslau, Der Profanbau. Zeitschrift für Architektur und Bauwesen, 14 (1905) 222.

6. Kirschke Pracownia Projektowa, Projekt budowlany Przebudowa budynku Rynek 29 - Oławska 2, gł. proj. arch. P. Kirschke, Wrocław 2013- 2014.

7. Lutsch H.: Verzeichnis der Kunstdenkmäler der Provinz Schlesien, T 1, Die Stadt Breslau, Breslau, Wilh. Gottl. Korn 1886, 143.

8. Łaba B.: Renesansowy dom „Pod Złota Korona” we Wroctawiu w: Dzieła i Interpretacje Wrocław, T. 1, FSHS 1993, 65-86.

9. Małachowicz E.: Stare Miasto we Wrocławiu, Wrocław, PWN 1985.

10. Stein R.: Das Breslauer Bürgerhaus, Tübingen, Ernst Wasmuth 1966. 


\title{
KAMIENICA „POD ZŁOTA KORONĄ” WE WROCŁAWIU - RENOWACJA OSOBLIWEGO ZABYTKU
}

\author{
Streszczenie
}

Wśród licznych historycznych budowli Wrocławia, znajduje się obiekt o adresie Rynek 29, ul. Oławska 2, wpisany w 1970 r. do rejestru zabytków jako Dom handlowy d. kamienica „Pod Złota Korona". Jego osobliwość polega na tym, że został wzniesiony w 1961 r. i nie jest to ani kamienica historyczna, ani dom handlowy. Obiekt ten stanowi w powojennej odbudowie historycznego centrum Wrocławia spektakularny przykład kreacji retrospektywnej, polegającej na wznoszeniu ważnych dla Starego Miasta, budowli ,zabytkowych”, niekoniecznie wiernie odtworzonych i znajdujących się na swym oryginalnym miejscu. Ponieważ budowano je na zrębach budowli historycznych, były w części podziemnej średniowieczne lub renesansowe, ale w części nadziemnej miały już konstrukcję szkieletową budynków komercyjnych $\mathrm{z}$ początku XX w. Wzniesione w oparciu o te elementy udatne stylizacje historycznych kamienic sprawiły, że szybko wtopiły się one w krajobraz i już po kilku latach w całości uzyskały rangę rejestrowych zabytków. Dziś nie wnikamy w szczegóły takiej nobilitacji wykreowanej niespełna 60 lat temu pseudostylowej architektury. Wydaje się ona uprawniona, gdy spojrzymy na walory kompozycyjne fasad tych obiektów, detal i jakość prac rzemieślniczych. W ostatnich latach pojawił się problem remontów i przebudów takich staromiejskich budynków, powiązany z naciskiem właścicieli na lokowanie w nich wyłącznie dochodowych funkcji. Rozpoznanie takich zabytków stało się wymogiem chwili. Bowiem tylko $\mathrm{w}$ ten sposób w przyszłości, w trakcie prowadzonych prac modernizacyjnych, będzie można uniknąć złych decyzji i nieprzewidzianych sytuacji.

Słowa kluczowe: Wrocław. powojenna odbudowa, historyczna kamienica mieszczańska

Editor received the manuscript: $16.03 .2015 \mathrm{r}$. 
